\title{
Repressão e resistência: lembranças de mulheres desafiando limites e desestabilizando fronteiras
}

\author{
Repression and resistance: remembrance of women defying limits and \\ desestabilizing borders
}

Represión y resistencia: recuerdos de mujeres desafiando límites y

desestabilizando fronteras

Sandra Nascimento Sousa:

\section{Resumo}

Este texto constitui-se a partir da rememoração de mulheres situando suas atuações políticas no contexto dos anos de 1960 a 1980 . Nesse sentido, tem a intenção de mobilizar reflexões sobre processos sócio-históricos que instituem a esfera pública de atuação como sendo "naturalmente destinada" ao exercício dos homens.

Palavras-chave: Memória política. Gênero. Mulheres.

\section{Encontrando mulheres no cenário político}

No teatro da Memória as mulheres são sombras tênues. Com essa frase Michelle Perrot (1989) provoca a reação de historiadoras e historiadores, falando da invisibilidade do sujeito mulher nos feitos históricos e na política, lugar no qual aparecem como excesso que transborda das fronteiras normativas do gênero. Em meus trabalhos de pesquisa, a atuação de mulheres, enquanto sujeito das

\footnotetext{
Doutora em Ciências Sociais pela Pontifícia Universidade Católica de São Paulo. Professora dos Programas de Pós-Graduação em Ciências Sociais e Cultura e Sociedade da Universidade Federal do Maranhão.
}

Recebido em 24/08/2012 - Aprovado em 05/12/2012 http://dx.doi.org/10.5335/hdtv.13n.2.3722 
ações que dinamizam processos e relações sociais, tem sido privilegiada nos espaços de festas como o Carnaval, no mercado de serviços sexuais e prazer, nos movimentos organizados em combate às desigualdades de gênero, raça, etnia. Essas atuações de mulheres tem sido centro de atenção e interpretações analíticas, baseadas em estudos de gênero que são levados a efeito no grupo de estudos que lidero: Gênero, Memória e Identidade - GENI, vinculado ao departamento de Sociologia e Antropologia e aos Programas de Pós-Graduação em Ciências Sociais e de Pós-Graduação em Cultura e Sociedade da UFMA, em São Luís do Maranhão.

Considero, entretanto, que ao situá-las como sujeitos de processos sócio-históricos, temos a responsabilidade de evitar o designativo mulheres como referencial abstrato, fora das condições sociais em que estão inseridas e dos marcadores classificatórios que as distinguem, em gênero, raça, etnia, geração e outros que clarificam e modificam experiências diversas.

Para esse texto, portanto, espero podermos dialogar a partir de recortes de resultados da pesquisa levada a efeito, para construção da minha tese de doutoramento, trabalhando com a memória de mulheres que, nos anos 1970 a 1980, nas cidades de São Paulo e São Luís do Maranhão, tiveram uma participação intensiva nos movimentos de mulheres na luta pelo combate à desigualdade de poder entre homens e mulheres, com a intenção de colocar em cena essa participação e as (re)significações possíveis no momento da pesquisa. Na ocasião, elas tinham em média entre 40 e 55 anos, residiam nas áreas urbanas de São Luís e em
São Paulo, em bairros de classe média, e em suas narrativas foi dada atenção para as experiências diversificadas entre brancas e negras. Outro destaque importante deve-se a serem mulheres que trabalhavam, naquele momento, em universidades, organizações não governamentais, institutos de pesquisa, organizações sindicais, partidos políticos. Essas mulheres empenhavam-se em atualizar seus objetivos, acostumadas ao hábito de participar, de lutar, desde a época de estudantes, em universidades, movimentos de base da Igreja Católica, associações de bairros, movimentos juvenis pela cultura e em outras instâncias.

Suas experiências, reunidas em lembranças que vivificaram suas trajetórias de vida, não deixam dúvidas quanto à contínua e sistemática participação de mulheres nesses ambientes contextualizados como espaços públicos. "As mulheres sempre estiveram por toda parte diz uma delas", fazendo aparecer histórias narradas pelos próprios sujeitos que as constroem, guardam e dinamizam com seus movimentos. Nesse sentido, o trabalho com a memória de grupos e de indivíduos tem muita importância quando busca atravessar os meandros das memórias oficiais e preencher espaços vazios, dúvidas, hesitações. Não há, então, um agente oficialmente destacado para enquadrar os fatos, precisar datas, registrar a pretensa verdade dos acontecimentos. $\mathrm{O}$ trabalho constitui-se com as interpretações de quem narra e de quem escuta, numa construção social e política de outras formas de situar os acontecimentos. 


\section{Como o diz Benjamin:}

[...] o narrador não está interessado em transmitir o puro em si da coisa narrada como uma informação, ou um relatório [...] No ato de narrar os sujeitos despreocupando-se de fornecerem as explicações, colocam as circunstâncias que envolvem suas vidas, os acontecimentos e, mesmo que os avaliem, deixam mais soltas as rédeas da imaginação... (1994, p. 223).

Constituídas como narradoras $23 \mathrm{mu}-$ lheres desfiaram com suas lembranças etapas importantes de suas vidas, que refletem conteúdos muito significativos para a história social de grande parte das mulheres que vivem nesse país. Nesse sentido, história oral e teorias da memória foram os instrumentos considerados privilegiados para a interação, escuta e análise do material extraído de suas narrativas.

Nesse recorte, as histórias vão se constituindo a partir de suas participações em movimentos de combate ao modo de produção capitalista, apoiadas em ideais marxistas, em prol de uma sociedade mais justa para todos via implantação do Socialismo, que, então era considerado porta-estandarte do progresso, propulsor da ideia de uma direção para a História, e de que tipos apropriados de intervenção política poderiam nos ajudar a acelerar essa empreitada.

\section{Mulheres nas lutas pela igualdade social}

Em meio às mulheres que, muitas vezes se embrenharam pelos caminhos do proibido, escuto suas narrativas irem se articulando, tecendo com gestos e sentimentos as tramas dessas suas histórias. Assim elas iniciam narrando:
[...] o meu envolvimento com a política está relacionado a uma coisa básica, à educação e à minha família, que era progressista politicamente. Uns eram socialistas, outros comunistas. Daí, fui educada para o compromisso e com a preocupação social. Já aos 13 anos estava ligada ao movimento da juventude estudantil católica (JEC ). Em 1967, saí da minha cidade e vim para São Paulo. Logo participei de passeatas contra a Ditadura Militar e das atividades dos Partidos Políticos de esquerda. Por conta dessas atividades, em 1968 fui presa... foi um período difícil no País, havia um clima de repressão e medo...

[...] no meu caso, fui militante de uma pequena organização a POLOC. Houve um racha e eu saí e fui pro MR8, mas saí em 1982 por não concordar com o estilo de trabalho, de política. As divergências eram muito grandes em função de questões ideológicas de fundo; a questão do modelo da União Soviética, toda a discussão que estava se dando em função do eurocomunismo, dos processos de transição que se vivia. Os militantes de esquerda já viviam em crise que estourou no final dos anos 1980, com o desmantelamento da União Soviética...

As lutas dos 8 de março foram feitas pelas forças de vanguarda, comunistas, socialistas...sempre houve os entreguistas, os golpistas, as forças conservadoras deste país, tentaram golpes com Café Filho, Getúlio Vargas. É uma história longa, que tinha trazido no seu bojo uma coisa, um grande desenvolvimento industrial, impondo um grande retrocesso ao sistema agrário do país. Então vão sendo criadas contradições que se aprofundam tanto no campo, como na cidade, e com tudo isso, esse momento põe em movimento grandes forças populares, e entre elas, também, as mulheres, e isso vai até $1964 \ldots$ as mulheres cresceram muito 
com todas essas lutas democráticas: campanha eleitoral de JK, Forças Nacionalistas do Exército, Forças Golpistas...

Anos 1950, 1960, 1970, 1980, todo um percurso de ação vai sendo traçado e recortado, aqui, por essas narradoras. Como diz Alfredo Bosi (1992, p. 19), "as datas da História são pontos de iceberg. É preciso ver o que está em baixo da superfície das águas". A história dos confrontos entre os grupos que compõem as relações de força no País, sempre foi contada ao modo dos vencedores, sem que fossem explicitadas as estratégias, as parcerias, ou os meios com os quais obtinham tais vitórias. E, no jogo da arena político-partidária, sindical ou das organizações de esquerda, a população masculina sempre foi dominante e sempre cuidou de registrar os seus feitos. Essas falas trazem à cena a atuação das mulheres.

Em plenos anos de 1950, as mulheres desse país eram representadas sob a designação de sexo frágil, ou segundo sexo. Ser mãe, esposa, dona de casa era considerado o destino natural das mulheres. Segundo Carla Bassanezi (1996, p. 109): "na ideologia dos Anos Dourados, maternidade, casamento e dedicação ao lar faziam parte da essência feminina, sem história, sem possibilidades de contestação". Atualmente, seria impensável reproduzirmos essas falas com o mesmo tom, à medida que, o que tínhamos como efeito discursivo, naquele momento, era um sujeito abstrato, modelo idealizado no processo de constituição original da família burguesa. Essa constituição se assenta sobre a divisão funcional e artificial dos integrantes do grupo família que reforça os mitos da mulher submissa, dominada e marido domi- nador, reproduzindo polaridades extremas, difíceis de serem visíveis como as únicas configurações de família e de indivíduos nas práticas sociais. Logo no início das narrativas daquelas que construíram, comigo, este trabalho, emergem mulheres que se distanciam muito dessas representações.

Narrando suas histórias, essas mulheres recortam da memória cenários, atuações, vivências de alegrias, de dores, de partilha com integrantes de outras organizações coletivas, num movimento que vai se construindo e desdobrando, apoiado no testemunho de pessoas de suas relações, passadas e presentes, cujos nomes, posições no grupo e na hierarquia da estrutura social, conservam-se nas suas lembranças, tecendo assim uma memória coletiva que ao ser esgarçada revela as tramas sociais de relações de poder por onde circulam dominação, subalternidade, tensões, conflitos e/ou revoluções.

Maurice Halbwachs (1970, p. 57) ressalta que a memória coletiva não é simplesmente o acervo de datas ou listas de fatos históricos. Acentua que: "reintegramos nossas lembranças em um espaço e, em um tempo sobre cujas divisões nos entendemos com os outros, que nós os situamos, também, entre datas, que não têm sentido senão em relação aos grupos de que fazemos parte".

A conjuntura exposta por essas lembranças configura um país pleno de contradições socioeconômicas e disputas pelo controle do Governo. Situa os anos de 1960, alternâncias constantes de silêncios e ruídos graves vindos da Ditadura Militar.

De acordo com uma das narradoras, que à época do trabalho de pesquisa, integrava o Conselho Estadual de Mulheres de 
São Paulo, as contradições socioeconômicas de nossa sociedade, naquela conjuntura, após uma fase precedente de desenvolvimento industrial e urbano, em que as expectativas dos analistas eram de crescimento econômico e ampliação de democracia política, expressavam-se em algumas crises que passaram a refletir forte compressão salarial, alterando negativamente o padrão de vida da maioria da população brasileira, o que, por sua vez, era articulado a um processo de acumulação de capital cada vez mais integrado ao sistema internacional. À medida que essas contradições acirravam-se, graves dificuldades econômicas envolviam o aparelho de estado e mobilizavam fortes reações populares.

O Partido Comunista Brasileiro, os grupos organizados de sindicatos e de entidades estudantis e, ainda, alguns segmentos da Igreja Católica, encarnando os ideais socialistas tornavam-se, naquele momento, canais expressivos para o engajamento daqueles que não aceitavam as desigualdades e as injustiças preservadas pelos poderes vigentes e, no interior dessas organizações, foi muito importante a presença das mulheres. As narradoras rememoram:

Como eu dizia, é toda uma história que envolve nossa atividade... a verdade é que de 1950 a mais ou menos 1964 as lutas femininas no país se desenvolviam de maneira bastante avançada. É quando surge a Federação Brasileira de Mulheres, depois o próprio JK fecha. Eram as lutas de bairros, lutas por distribuição de gêneros, controle de gêneros nas empresas, tudo resultado das contradições que falei antes. Em 1964, as mulheres foram golpeadas, tiveram de recuar, foi muita bordoada, só lentamente as mulheres vão se reerguendo...
[...] 1964, foi o começo de anos difíceis de serem vividos por nós... fui presa em 1969, eu estava grávida, tinha casado em 1968. Meu marido militava no Partidão. Isso me aproximou muito mais das atividades do partido. Eu e meu marido passamos um tempo no DOPS e ali a gente conseguiu uma forma de se comunicar, trocávamos bilhetinhos. Foi uma experiência que deixou marcas... o temor permanece dentro da gente, como uma coisa que não precisava ter expressão ou reação de uma manifestação concreta. A gente viveu assustada, mesmo quando aquilo não existia fisicamente... uma coisa muito difícil...

A maioria das narrativas destaca lembranças portadoras de acontecimentos ocorridos desde o contexto marcado pelo Governo Militar. Apoiados nas ideologias da Segurança Nacional e do Progresso com Ordem, os segmentos dirigentes imprimiam força repressiva por meio de Atos Institucionais, por exemplo, correspondente ao temor que sentiam da força dos ideários correntes entre os grupos revolucionários de oposição.

No processo de detenção em prisões e de submissão a torturas, algumas narradoras lembram do autocontrole a que se impunham para evitarem denunciar seus companheiros de militância. Escondiam nomes, lugares e temiam, também, pela segurança de seus familiares. Silêncios, esquecimentos, lágrimas retidas passaram a integrar os tecidos dessas lembranças. Alguns desses elementos constituem o que Pollak (1989, p. 3) considera como fertilizantes para memórias subterrâneas: zonas de sombra e não ditos que se instalam no seio dos grupos dominados diante das ameaças de serem punidos ou mal entendidos ao falarem dos acontecimentos que vivenciaram. Para Pollak: 
[...] a fronteira entre o dizível e o indizível, o confessável e o inconfessável, separa a memória coletiva subterrânea de segmentos da sociedade da memória coletiva organizada, que resume a imagem que uma sociedade majoritária ou o Estado deixam passar e impõem... (POLLAK, 1989, p. 6).

As narrativas apontam para a necessidade histórica da construção de perspectivas diferenciadas sobre o elo modernização/desenvolvimento do país em relação às propostas dos governantes, que, àquela época, enfatizavam a segurança como instrumento fundamental ao desenvolvimento, modelo que era considerado expropriador das classes consideradas subalternas. Constato a vivacidade com que essas lembranças são expressas. Flutuantes entre clareza, omissões, esquecimentos trazem o passado ao presente e encarnam a necessidade de reproduzirem os acontecimentos como instrumento de alerta no sentido de evitarmos que tais processos e relações sociais possam se repetir.

A reminiscência, como ressalta Benjamin (1994) é a musa épica que transmite os acontecimentos de geração em geração. Utilizada como recurso metodológico, nos possibilita termos na História os sujeitos vivos; sua ação integrada aos sentimentos experimentados nas vivências que vão sendo recortadas pelas suas lembranças. Para Teresinha Bernardo (1988, p. 177): “os sentimentos experimentados, também, são zelosamente guardados e, no ato de lembrar, vem à tona com intensidade, filtrados, avaliados, assumidos e preenchidos com novos significados, a partir da vivência do presente".

\section{Outra narradora acrescenta:}

Comecei no PC do B, que era um partido clandestino e que tinha uma atuação bem grande no movimento secundarista. Então comecei no colégio em Campinas. Fizemos um trabalho de conscientização na escola. Eu já tinha 17 anos e já frequentava um grupo que discutia, também a questão racial. Nos anos 1970 eu andava um pouco paranoica, porque as pessoas andavam sumindo... tinha uma amiga minha que se suicidou, jogou-se de uma ponte, ela andava sendo perseguida. Eram fatos que estavam me chocando muito naquela época... nunca mais tinha me lembrado disso... não pensei que estava tão vivo na minha memória.

Essa fala é acompanhada de lágrimas que remetem à perda da amiga. Para Benjamin, a narrativa não transmite o puro em si da coisa narrada, como um relatório: "Ela mergulha a coisa na vida do narrador para em seguida retirá-la dele. Os seus vestígios estão presentes de muitas maneiras nas coisas narradas, seja na qualidade de quem as viveu, seja na qualidade de quem as relata".

As mulheres destacam suas ações afirmativas, revelando-se conhecedoras dos problemas, contradições e conflitos que compõem a conjuntura do país. Conhecendo-os, determinam-se a participar de todo movimento que possibilite o encaminhamento de soluções. São mulheres que tiveram a possibilidade de frequentar regularmente faculdades, organizações estudantis, partidos políticos. Tiveram, portanto, acesso à instrução mais qualificada, a leituras, círculo de debates políticos, questionamentos críticos.

Essas mulheres desviam-se, muitas vezes, de rotas traçadas social e previamente, 
segundo o modelo ideal de feminilidade em vigor. $\mathrm{O}$ casamento e a maternidade não se constituíam como metas exclusivas de realização. Imbricavam-se em territórios considerados masculinos e, é neles que assentavam sua marca diferenciada. Punham-se no jogo das relações de poder, exatamente onde o Poder, no singular, era pensado como designando basicamente à figura central do Estado, comumente associado à figura masculina. Deslocavam-se de um lugar para outros, nos diversos movimentos dos anos 1960, 1970, 1980, colocando o seu jeito de ser, expressando-se de maneira diferenciada do padrão de comportamento assumido nas diversas organizações.

Essa narradora, por exemplo, destaca:

Eu era uma ativista do Partido Comunista, lá eu fazia de tudo. Eu não tinha cargo importante na hierarquia do Partido, mas eu era importante, tanto que me entregaram o serviço da imprensa, e a imprensa é o cérebro do Partido, não é mesmo? Eu não tinha carteirinha do Partido, mas era muito importante a minha atuação... Hoje sou uma colaboradora em Partido Político, mas não quero filiação...

\section{Outra narradora comenta:}

Como militante do Partidão eu não tinha carteirinha. Fazia política sem isso da filiação ao Partido. Me chocava ter que, eventualmente, entrar numa decisão partidária que eu não concordava... eu não conseguia perder essa autonomia... fazer uma coisa que eu considerasse desonestidade intelectual... concordar com uma coisa e ter de fazer aquilo porque o Partido tinha decidido. As decisões partidárias, ainda hoje, são assim e, naquela época, ainda mais, um pouco dogmáticas... era um pouco assim: quem não é de esquerda é de direita... quem não é do Partido é anticomunista... era uma coisa muito ortodoxa, ou isso... ou aquilo.
Segundo Perrot (1998, p. 177), a partir do séc. XIX, organiza-se uma distinção específica entre o público e o privado, como esferas teoricamente separadas, promovendo-se correlatamente um discurso naturalista que insiste na existência de duas espécies com qualidades e aptidões particulares: "aos homens o cérebro (muito mais importante que o falo), a inteligência, a razão lúcida, a capacidade de decisão. Às mulheres, o coração, a sensibilidade, os sentimentos". Estes são pressupostos que permeiam os processos de socialização de homens e mulheres e que, em meio a outros discursos de igualdade e liberdade, na contemporaneidade, persistem como marcadores sociais de distinção que se fixam na diferença sexual como referente da identidade de gênero.

A afirmação dessas mulheres, nos Partidos Políticos, se dá pela competência que demonstram em suas atuações. Compromisso, responsabilidade, além da autonomia que pretendem impor a si mesmas. A maior parte do grupo que integrou este trabalho manifesta esse desejo de liberdade, de fazer aproximar seus princípios das práticas efetivadas, buscando, porém, agir de forma diferenciada dos homens, nas organizações. Daí, preferirem, em muitos casos, posicionar-se como colaboradoras dos partidos políticos e não como militantes de carteirinha. Essa decisão, que muitas vezes, foi apontada como sendo imposição dos homens, nessas narrativas, aparece como um esforço das próprias mulheres para resguardarem princípios que lhes pareciam caros. Creio que, também, demarcavam horários mais flexíveis para cumprirem as jornadas de trabalho no espaço da casa e da família. 
A psicanalista Maria Rita Kehl (1988, p. 38) destaca que modernidade, urbanização, industrialização, organização da vida pelos parâmetros da eficácia industrial e da moralidade burguesa, nascimento da família nuclear, separação nítida entre os espaços privado e público - a esse conjunto de mudanças, que em menos de cem anos, modificou a sociedade europeia e se irradiou para todas as sociedades ocidentais - corresponde a um novo tipo de sujeito: naquele contexto histórico de valorização da personalidade, a vida de cada um passa a ser um campo de significações, que é mais um passo na responsabilização dos sujeitos modernos.

As narrativas nos fazem conhecer um sujeito atrelado a ideais representados na figura da militante. As palavras justiça social, compromisso, autonomia e luta social ligam-se a conteúdos fortes como à uma missão atribuída e sobre a qual as narradoras referenciam sua identidade. Identidade e missão são apontadas como figuras fixas, um lugar de onde era possível dizer eu sou militante... eu fui militante.

Suely Rolnik (1998) ressalta que a identidade é um conceito de referenciação; é aquilo que faz passar a singularidade de diferentes maneiras de existir por um só e mesmo quadro de referência identificável. Para ser identificado a uma missão, o sujeito tem que se ater aos quadros dessas referências, o que no caso destas narradoras vai sendo fixado como um sujeito que orienta sua conduta para fazer acontecer a mudança social, aquela que no contexto de seus discursos, realizará os ideais de liberdade, igualdade e fraternidade. Em suas pautas é fundamental ser militante de esquerda para construírem uma outra ordem social. Nesse sentido, uma das narradoras destaca:

Era um pouco assim, quem não é de esquerda é de direita... quem não está no Partido é anticomunista. No mundo da repressão essas coisas acabavam sendo acirradas, o sectarismo, o radicalismo... o fato de se acabar vivendo no gueto, não autoisolado, mas isolado pela própria sociedade, uma vez que numa democracia como aquela não se pode fazer política abertamente.

A narrativa seguinte é expressiva sobre o modo de comportamento nas organizações políticas e ressalta situações conflitivas que expõem a posição e os lugares dos sujeitos, intercruzando fatores ligados ao gênero, à ação politizada e às obrigações impostas aos seus integrantes:

Na clandestinidade eu fiz meu segundo aborto... esse aborto gostaria de pontuar... eu era clandestina, fazia parte do Partido Operário Comunista (POC) e a gente discutiu muito essa gravidez na organização e a organização achou por bem... nós decidimos que eu devia abortar, porque um filho já me impedia muito de militar. Complicava, porque eu tive minha filha em 1969, o embaixador havia sido sequestrado, a situação estava difícil e ter um outro filho àquela hora ia ser muito difícil. A lógica que levou a organização a decidir que eu abortasse era a lógica de que iria prejudicar a minha militância e a minha lógica era de que eu não ia dar conta, mas de uma maneira, ou de outra eu participei dessa decisão pela organização. Olhando o passado, eu vejo que aquela decisão estava certa, mas olhando agora, eu vejo, também, que foi uma decisão onde o meu individual não foi levado em conta, a minha subjetividade... também, hoje, não sei qual era minha subjetividade naquele momento, de verdade as coisas eram misturadas... mas eu acho que foi uma coisa muito pesada na minha vida. 
De acordo com Figueiredo (1995, p. 119), os discursos de autolegitimação da militância revolucionária transitam sobre eixos de referência bem visíveis. Um deles, que diz respeito ao serviço prestado, reivindica para o militante a condição de verdadeiro sujeito, por ser o intérprete abnegado de uma causa a cuja vontade se assujeita integralmente, incorporando-a e renunciando a qualquer direito individual os elementos, aqui, reportam-se à obediência ao partido e à disciplina.

Retomando suas narrativas, as mulheres, em certo momento, vão registrando mudanças no conjunto das relações vigentes:

No momento em que saio do Brasil, em 1970, as mulheres começavam a fortalecer seus movimentos organizados. A primeira coisa forte nesse sentido é o movimento das mães, querendo salvar seus filhos, libertar aqueles que haviam sido presos por ocasião do Congresso em Ibiúna... é um primeiro movimento positivo na direção da anistia, que cresceu pela Anistia Geral Irrestrita. Essa campanha veio somada a outras lutas, consequências do Golpe, a carestia de vida. As mulheres tinham que trabalhar fora porque a miséria estava muito grande. Para trabalharem as mulheres precisavam deixar seus filhos em algum lugar. Daí vem outra luta, pelas creches e ...vai assim até meados de 1970, quando começam a se realizar encontros de mulheres no Rio de Janeiro e em São Paulo.

Na década de 1970, eu trabalhava como professora primária em Belo Horizonte. Eu fazia parte do Sindicato de Professores e estava na POLOP, uma dissidência do Partido Comunista, que já havia rachado. $\mathrm{Eu}$ já tinha três preventivas decretadas. Estava casada e com uma filha, quando fui presa em 1971, em São Paulo, foi um momento de muita violência, mas também de muita grandeza, porque conheci outras mulheres com as quais aprendi a conviver ...mulheres que mataram o marido, filho ou um amante. Não seria quem sou hoje sem essa experiência de conviver com $o$ outro, o diferente e conceber a dimensão de sua dor. Muitas de nós que fomos presas ou exiladas criamos o movimento feminista com essa base muito forte. Acho que se conseguiu ali, trazer à luz, as lutas das mulheres, o seu lugar na sociedade, na história do movimento político... eu acho isso muito forte.

As narrativas vão seguindo seu curso no andamento de um tempo que não se fixa, exclusivamente, em cronologias. Trata-se de acontecimentos sociais e históricos preenchidos com personagens, motivos, movimentos objetivados. Os acontecimentos são coloridos com as emoções que os significam. Essa noção de tempo é correspondente ao que Halbwachs chama de tempo real, o tempo que tem um conteúdo, isto é, oferece um conteúdo de acontecimentos ao pensamento. É, ainda, o tempo vivido, que lhes permite, naquele momento, ressignificar aquelas situações e descobertas feitas nas organizações. Como diz Alfredo Bosi: "é um tempo que a presença humana qualifica". Nesse caso, a presença das mulheres.

\section{Mulheres e mudanças nas relações de gênero}

Segundo Anette Goldberg (1989), no bojo da sociedade brasileira, dos anos 1960, à qual já haviam chegado as pílulas anticoncepcionais, muitas jovens começaram a sentir-se incomodadas com seu destino de gêenero, passando a questionar valores morais e 
comportamentos estabelecidos, colocando-se questões a respeito de sua identidade e sexualidade, da liberdade e do amor. Algumas mulheres que, naquela conjuntura, tinham aproximadamente, entre 20 e 30 anos, frequentavam ambientes acadêmicos, grupos políticos organizados, associações estudantis, passaram a opor-se, radicalmente, àqueles códigos e orientações que tiveram forte consistência nas práticas relacionais da geração de suas mães, e, que lhes foram transmitidos nos processos de socialização, especialmente no âmbito de suas famílias.

Abrindo caminho para a defesa de seus interesses específicos nas lutas sociais, essas mulheres desvelam diversas outras estratégias de poder que tinham efeitos nas relações desiguais entre mulheres e homens. Lembrando de seus movimentos, elas destacam:

Eu tive contatos com grupos de mulheres nos anos 70 e isso fazia eu me movimentar, ter uma outra leitura de vida, embora já no grêmio da escola me chamasse atenção que os rapazes eram sempre os líderes, já comentávamos isso entre as amigas. Já estava acontecendo um processo na Europa, as mulheres se rebelando, colocando a questão do segundo sexo... começávamos a discutir isso e os rapazes diziam que não, que a luta maior deveria ser contra a Ditadura Militar. Eu já entendia que era contra toda forma de poder, inclusive de um sexo sobre outro. No nosso grupo tinha um líder por quem fui apaixonada, e tínhamos muita discussão sobre isso... ele saiu da liderança da organização e eu seria a substituta natural, mas não fui aceita, por ser mulher, fiquei muito brava e rompemos o namoro...

Organizamos o $1^{\circ}$ Congresso da Mulher Paulista em 1979 e a gente rebenta com instituições e preconceitos. A própria esquer- da era contra nós. A direita, nem se fala! Na esquerda, se dizia que esse era um movimento de mulheres de classe média, que não tinha a ver com as questões do povo. Violência? Se as mulheres apanhavam do marido, na visão deles, era por causa da exploração do capitalismo que explorava os homens. A questão do aborto, da contracepção?... isso não era importante. Falar do casamento, do amor, do corpo?... isso era coisa de burguês...

Benjamin (1994) lembra-nos que as narrativas tecem as redes que todas as histórias constituem entre si: "comum a todos os narradores é a facilidade com que se movem para cima e para baixo nos degraus de sua experiência, como numa escada. Uma escada que chega até o centro da terra e que se perde nas nuvens".

A rememoração dessas mulheres desvela o momento em que as diferenças de cor de pele, gênero, classe e tantas outras, naturalizadas em diversos discursos científico-especializados, como na psiquiatria, biologia, pedagogia e outros, são reconhecidas como fundadoras de desigualdades e discriminações. As classificações de sujeitos, estabelecidas em marcadores hierárquicos pressupunham vetores polarizados em torno dos eixos natureza e cultura, sobrevalorando as associações feitas a um desses eixos em detrimento do outro, o que encaminhou discussões e análises, por parte das mulheres, sobre a construção sociopolítica do gênero em modelo dualista e à sua reprodução constante pelas mais diversas tecnologias sociais.

A intensidade dos novos movimentos sociais, em prol do direito à diferença, mobilizava reações de todo tipo, sendo que uma das preocupações mais prementes, situava- 
-se em relação ao que se designava como lutas sociais de combate a um modo de produção que gera desigualdades e exploração - o capitalismo - e às lutas sociais de combate à discriminação por estar o sujeito inserido em uma determinada classificação de gênero, de cor da pele, de etnia, ou de orientação sexual específica.

Uma das narradoras situa suas lembranças, destacando:

[...] eu vim participar de movimento organizado na década de 1980, primeiro no Coletivo de Mulheres Negras, do qual fui uma das fundadoras, depois fundamos um outro grupo, hoje uma ONG. O Coletivo de Mulheres Negras nasceu de uma reação das mulheres negras à criação do Conselho Estadual da Condição Feminina sem a participação das mulheres negras. Surgiu em meio à incitação da jornalista Marta Arruda, que, ao saber que as mulheres negras não participavam abriu uma campanha de denúncias e começou a congregar mulheres negras ativistas, o que resultou no Coletivo e, em darmos posse a mulheres negras no Conselho.

O movimento de mulheres negras nasce dentro dos encontros feministas, da necessidade de discutirmos nossas questões de identidade, de autoestima, que eram diferentes das histórias da mulher branca. Esta já veio da sociedade de outra forma, mais ou menos estruturada, em todos os sentidos, de família, de afetividade, de vida profissional e, a mulher negra, não [...]

Para Sueli Carneiro e Thereza Santos (1985, p. 43) as mulheres negras vêm de uma experiência histórica diferenciada, alinhada com a perda do poder de dominação do homem negro, por sua situação de escravo, pela sujeição ao homem branco opressor e pelo exercício de diferentes estratégias de resistência e sobrevivência. As condições em que vivia a população negra, durante a escravidão, não permitiam ao homem negro exercer sobre a mulher negra a opressão paternalisticamente protetora a que estavam submetidas as mulheres brancas "[...] igualmente, as relações estabelecidas entre homens brancos e mulheres negras, evidentemente, estavam longe de reproduzir as formas de opressão características das relações de gênero entre os brancos".

Reconstituindo suas experiências, as lembranças remetem-se a um contexto social amplo, que é percebido como marcado por fronteiras que precisavam ser desestabilizadas, como as que dizem respeito ao público e privado, assim como as que unem e separam os sujeitos em função de sua etnia, ou cor da pele.

Bergson (1990) ressalta que a função da memória é libertadora e criadora: "retém o passado para organizá-lo com o presente em uma articulação rica e nova". Balandier (1999), em sintonia com essa compreensão, ressalta que a memória não representa só o passado, mas joga com ele, prolonga seu efeito útil até o momento presente. Insiste em que é de vida e de experiências vividas que precisamos nesse final de século caracterizado por muitas desconstruções, banalizações das comemorações, que se multiplicam por todos os lados. A seu ver, "a convocação do passado, os apelos à memória coletiva manifestam, ainda, a busca de respostas para nos situarmos no mundo, onde as referências são bastante instáveis".

Outras vozes registram: 
Passados mais de vinte anos a gente nem imagina o que foi no começo [...] a gente olha e parece que foi fácil, mas não foi, os próprios negros iam para as reuniões um tempo, depois desapareciam. Em 1979, já tinham muitos movimentos negros, em São Paulo, no Rio de Janeiro. Comecei a reunir gente, fazer debates, estudar, fiquei como coordenadora de um grupo, tinha livros, contatos, arranjei estatutos, e, assim ia nascendo o Centro de Cultura Negra, em São Luís.

Muito constantemente, as lembranças iam dando conta de muitas especificidades que fragmentam a unidade reconhecida como mulheres, revelando o conteúdo significativo dentro dos diversos grupos, trazendo à cena do político a presença dos afetos, da sexualidade, dos conflitos gerados pelas diferentes posições de sujeito do gênero, fazendo com que as coisas chamadas privadas se tornassem visíveis no espaço público, alargando a noção da política. As narrativas dão ênfase às diversas ondulações do movimento organizado por mulheres e das avaliações feitas no momento da pesquisa:

[...] eu me sinto parte do sucesso que o movimento alcançou. Tenho uma filha e, para ela, para essa turma de jovens é tão natural e, até folclóricas, determinadas proibições que, para mim, eram correntes, já encontraram o mundo com um grau de igualdade de oportunidades que eu não tive. E, é evidente que existem, hoje muitas mulheres em cargos públicos, atuando nas mais diversas profissões, mas é no espaço das relações cotidianas que temos que mudar mas... me preocupa essa coisa da mulher negociar a sexualidade com o marido, com o companheiro, a questão da confiança, da contaminação das mulheres pela Aids, isto revela a dificuldade de negociação das mulheres. Ainda há uma condição pré-histórica, mesmo para as mulheres que tem melhores condições, informação, parece que tem uma trava, como se no plano emocional, não tivesse nenhum avanço para os dois.

[...] esse movimento para mim foi o mais importante do século XX. As questões da desigualdade vieram à luz do dia, mostrou-se claramente como são construídas as relações de opressão entre homens e mulheres. Foi uma grande ruptura na mentalidade, ao se colocar que o corpo da mulher não era só um corpo, meramente reprodutor [...] na área do conhecimento científico gerou-se uma crise paradigmática, no conhecimento racionalista, positivista e, mesmo, no marxismo ortodoxo, a partir de se dizer que a linguagem reside na coisa... que o sujeito se constitui num processo [...] muita coisa foi quebrada, rompida nas relações de gênero, mas ainda temos muitos desafios ligados às políticas de gênero e, este é um conceito que precisa muito ser entendido e trabalhado... gênero não é só hierarquia entre os sexos [...]

Consideramos essas falas como portadoras de uma experiência social que envolveu grande contingente de mulheres, para além das que exerciam militância ativa, alterando, irreversivelmente, muitas práticas das relações de gênero, tais como destaca uma das narradoras:

[...] mudou essa fixidez na sexualidade hétero, de se ver o sujeito como sendo branco, homem e heterossexual... isso foi quebrado, rompido. Na política, tanto sindical, quanto partidária, as mulheres ampliaram sua atuação, puderam discutir a questão de cotas e, até mesmo, nos meios de comunicação se vê alguma mudança, mas acho que, ainda, se tem muito por fazer.

Finalizo, então, em sintonia com a historiadora Joan Scott, na reafirmação de que o lugar que as mulheres ocupam na socie- 
dade está determinado, principalmente, pelos sentidos que adquirem as atividades por elas exercidas, o que de um outro modo, quer dizer que as experiências concretas das mulheres, assim como os sentidos que tais práticas assumem no discurso dominante, estão imbricadas em relações de poder historicamente determinadas. (Re)conhecer isto já é sinal de grande mudança.

\section{Abstract}

The present text was built from the remembrance of women, situating their political performances in the context of the years 1960 to 1980 . In this sense, it intends to mobilize reflections on sociohistorical process that founds the public sphere of agency as naturally intended to the exercise of men.

Keywords: Political memory. Gender. Women.

\section{Resumen}

Este texto se constituye a partir de la rememoración de mujeres situando sus actuaciones políticas en el contexto de los años 1960 a 1980. En este sentido, tienen la intención de movilizar reflexiones sobre los procesos socio históricos que instituyen la esfera pública de actuación como siendo "naturalmente destinada" al ejercicio de los hombres.

Palabras-clave: Memoria política. Género. Mujeres.

\section{Referências}

ALAMBERT, Zuleika. Mulher: uma trajetória épica. São Paulo: Imprensa Oficial do Estado S/A, 1997.

BACHELARD, Gaston. A dialética da duração. São Paulo: Ática, 1994.

BALANDIER, Georges. O Dédalo. São Paulo: Bertrand Brasil, 1999.

BASSANEZI, Carla. Virando as páginas, revendo as mulheres - revistas femininas e relações homem-mulher: 1945-1964. Rio de Janeiro: Civilização Brasileira, 1996.

BENJAMIN. Walter. Obras escolhidas: magia e técnica - arte e política. São Paulo: Brasiliense, 1994.

BERGSON, Henri. Matéria e memória: ensaio sobre a relação do corpo com o espírito. São Paulo: Livraria Martins Fontes Editora, 1990.

BERNARDO, Teresinha. Memória em branco e negro: olhares sobre São Paulo. São Paulo: EDUC/Fundação Editora da UNESP, 1998.

BOSI, Alfredo. O tempo e os tempos. In: Tempo e história. São Paulo: Companhia das Letras, 1992.

CARNEIRO, Suely. Identidade feminina. In: SAFFIOTI, Heleith e VARGAS, Mônica. Mulher brasileira é assim. Rio de Janeiro: Rosa dos Tempos, NIPA/UNICEF. Brasília-DF, 1994.

CARNEIRO, Suely; SANTOS, Thereza; COSTA, Albertina. Mulher negra: política governamental e a mulher. São Paulo: Nobel/Conselho Estadual da Condição Feminina, 1985.

Cadernos PAGU (6/7): Raça e gênero. Núcleo de Estudos de Gênero/ UNICAMP. Campinas-SP, 1996.

COSTA, Albertina de O. Prismas sobre o feminismo. In: Natureza, História e Cultura: repensando o social. v. 4, n. especial (1993). Porto Alegre: PPGCS/UFRGS, 1993. 
EVERS, Tilman. Identidade: a face oculta dos movimentos sociais. In: Revista Novos Estudos CEBRAP, n. 4. Abril, 1984.

FIGUEIREDO, Cláudio. Modos de subjetivação no Brasil e outros escritos. São Paulo: Ed. Brasiliense, 1985.

GOLDBERG, Anette. Feminismo no Brasil Contemporâneo: o percurso intelectual de um ideário político. In: BIB. Rio de Janeiro, n. 28, $2^{\circ}$ semestre de 1989.

HALBWACHS, Maurice. A memória coletiva. São Paulo: Vértice/Ed. Revista dos Tribunais, 1970.

KEHL, Maria Rita. Deslocamentos do feminino: a mulher freudiana na passagem para a modernidade. Rio de Janeiro: IMAGO, 1998.

PERROT, Michelle. Mulheres públicas. São Paulo: Fundação Editora da UNESP, 1989.

Práticas da memória feminina. In: Revista Brasileira de História. São Paulo, v. 9, n. 18, ago/set. 1989.

POLLAK, Michael. Memória, esquecimento e silêncio. São Paulo: Ed. Revista dos Tribunais/ Publicações Estudos Históricos, 1989.

ROLNIK, Suely. Cartografia sentimental: transformações contemporâneas do desejo. São Paulo: Estação Liberdade, 1989.

SAFFIOTI, Heleieth. Diferença ou Indiferença: gênero, raça/etnia, classe social. In: ADORNO, Sérgio (Org.). A sociologia entre a modernidade $e$ a contemporaneidade. $\mathrm{N}^{\mathrm{o}}$ especial do Caderno de Sociologia (1995). Porto Alegre: PPGS/ UFRGS, 1993.

SCOTT, Joan W. Prefácio à Gender and Politics of history. In: Cadernos PAGU (3): desacordos, desamores e diferenças, 1994. 